\title{
Intensification of Sorghum Production in Flood Recession Agriculture in Yelimane, Western Mali
}

\author{
Kalifa Traore ${ }^{1}$, Bouya Traore ${ }^{2}$, Gry Synnevåg ${ }^{3}$ and Jens B. Aune ${ }^{3, *}$ \\ 1 Institute of Rural Economy (IER), Regional Center of Agronomic Research of Sotuba/Soil-Plant-Water \\ Laboratory, Bamako BP262, Mali; ibosimon_1@yahoo.fr \\ 2 Institute of Rural Economy (IER), Regional Center of Agronomic Research of Gao Program of Natural \\ Resources Management, Gao BP258, Mali; bouyatr1@gmail.com \\ 3 Noragric Department of International Environment and Development Studies, Norwegian University of Life \\ Sciences, P.O. Box 5003, N-1432 Ås, Norway; gry.synnevag@nmbu.no \\ * Correspondence: jens.aune@nmbu.no
}

Received: 15 April 2020; Accepted: 15 May 2020; Published: 19 May 2020

\begin{abstract}
Flood recession farming is as an important supplement to rainfed agriculture in West Africa. Every year, large areas are flooded along riverbanks and temporary lakes. When water recedes from the flooded areas, farmers plant crops. This study describes the flood recession farming in the Yelimane district of Kayes region in Mali and assesses different ways to intensify the system. The use of external inputs in this system is minimal. Field experiments were undertaken over two years to test crop establishment methods, soil tillage, increasing plant density, use of organic and mineral fertilizer, and improved varieties. These technologies increased sorghum yield as compared to the control in the following descending order: Seed priming + fertilizer (77.1\%), NPK + organic fertilizer $(74 \%)$, seedling transplantation + micro fertilization $(61.3 \%)$, improved varieties $(49 \%)$, mounding $(34 \%)$, and urea application $(24.9 \%)$. The technology seed priming in combination with mineral fertilizers was promising because of the high yield and the low labor demand. Nitrogen fertilizer is needed in flood recession agriculture as the soils and the deposited sediments are low in nitrogen. Farmers' choice of technology will depend on the yield level, net return per hectare, labor use, and access to inputs.
\end{abstract}

Keywords: farm characteristics; sediments; tillage; crop establishment; nitrogen; microdosing; seed priming; planting density; varieties

\section{Introduction}

Crops grown in flood recession agriculture use residual soil moisture that is stored in the soil profile after water recedes from annually inundated floods plain, temporary lakes, or seasonal wetlands. Cultivation in the Nile delta in Egypt is the classical example of flood recession farming [1]. Soils in flood recession farming are relatively rich as the yearly flooding brings sediments that are deposited in the flooded area [2]. The major area for flood recession farming in Mali is in the temporary lakes flooded by the Niger river in the districts of Goundam and Dire (Tombouctou region). It was assessed that 250,000 ha is under flood recession in Mali [3]. However, there is a high year-to-year variation in land available for flood recession farming as a result of variable flooding in the watershed. In years of amble flooding (more water in rivers), there can be 2 to 3 times as much land available for flooding compared to a year with low flooding [4]. Crops not only utilize water that is stored in the soil profile but also benefit from the capillary rise of water. In Yelimane district in northwestern Mali, flood recession farming is practiced in the temporary lakes Terekole, Kolombine, and Magui. These lakes are flooded as a result of direct precipitation on the floodplain, and runoff from areas at a higher elevation in the watershed. Flood recession farming is vital for food security in the district as rainfed farming is 
unpredictable due to erratic rains [5]. The average yield in Yelimane in flood recession farming for sorghum and maize is 750 and $800 \mathrm{~kg} \mathrm{ha}^{-1}$, respectively [2].

In Mali, two types of flood recession farming are practiced. In one type, the crops are sown following the withdrawal of water from flooded areas and the crop develops only using water stored in the soil [6]. For this type of flood recession farming, the farmers use sorghum varieties of the Durra type. In the other type of flood recession farming, sowing follows the drying of depression in temporary lakes. The sorghum plants will be grazed down in the dry season to reduce respiration from plants. When the rainy season starts, the crop will develop depending on the rainfall or water accumulated in the depressions. In this type of flood recession farming, sorghum varieties of the Guinean type are used. Flood recession sorghum varieties can generally be characterized by a strong stalk, a well-developed root system, and dense panicles in order to reduce bird attack [6]. Sorghum varieties used in flood recession farming are generally photosensitive varieties that arrive at maturity on the same period every year independent of the date of sowing. This study focused on the first type of flood recession farming.

Labor input in flood recession farming is normally less compared to in rainfed agriculture because the soil is not tilled prior to sowing [7], and weeding is less demanding due to lower weed infestation as the land is flooded for months every year [4]. It is estimated that $72 \%$ of the labor demand in flood recession sorghum production is used for guarding the harvest against seed-eating birds [8].

The vast floodplains in the Yelimane areas are largely underutilized for flood recession farming due to the lack of hydro-agricultural development. Yearly flood water of the Terekole, Kolombine, and Magui (TKM) lakes inundates a vast alluvial plain of 70,000 hectares, including the northeastern part of the Kayes region (north-west of Mali) and southern part of Mauritania [8]. Potentially, this area can be cropped after the recession of flood water. Flooding in the Yelimane area begins in the end of July. The water level in the lakes reach the highest level in mid-September; thereafter, water recedes gradually until the end of October. Water withdrawal can be fast, as $50 \%$ of the maximum flow can entirely recede during a 10-day period. Floods and the recession of water in the lakes can be regulated using percolating dikes and/or the construction of dams [9]. Work has been undertaken in Kemala village in the Yelimane district to regulate water flow [10].

The objective of this study was to characterize flood recession farming in the Yelimane district of Kayes region in Mali, and to assess options for increasing the yield of sorghum in this flood recession system. Tested technologies included seed priming, use of improved varieties, micro-dosing of organic and mineral fertilizers, transplanting of seedlings, mounding (mounds are heaps of soil that are $10 \mathrm{~cm}$ high and with a $30 \mathrm{~cm}$ diameter), and pesticides. These technologies were included as they have been proven efficient at increasing productivity at a low cost in rainfed sorghum production in the Sahel [11], and in preliminary on-farm testing of these technologies under flooded recession agriculture in the Yelimane district [12]. To this date, there have been very few studies that have assessed the different ways of improving flood recession farming in Mali and elsewhere in Africa.

\section{Materials and Methods}

\subsection{Study Sites}

The study was conducted from 2014 to 2016 in the northwestern part of Mali (Kayes region) in Yelimane district (Figure 1) with $15^{\circ} 3^{\prime} 52^{\prime \prime}$ North, $10^{\circ} 33^{\prime} 57^{\prime \prime}$ West as geographical coordinates. Villages involved in in the study site were Gory, Yaguine, Dougoubara, Foungou, and Kemala. These study sites were chosen because of their importance for flood recession farming in Mali and because this is an area that is very vulnerable to drought. 


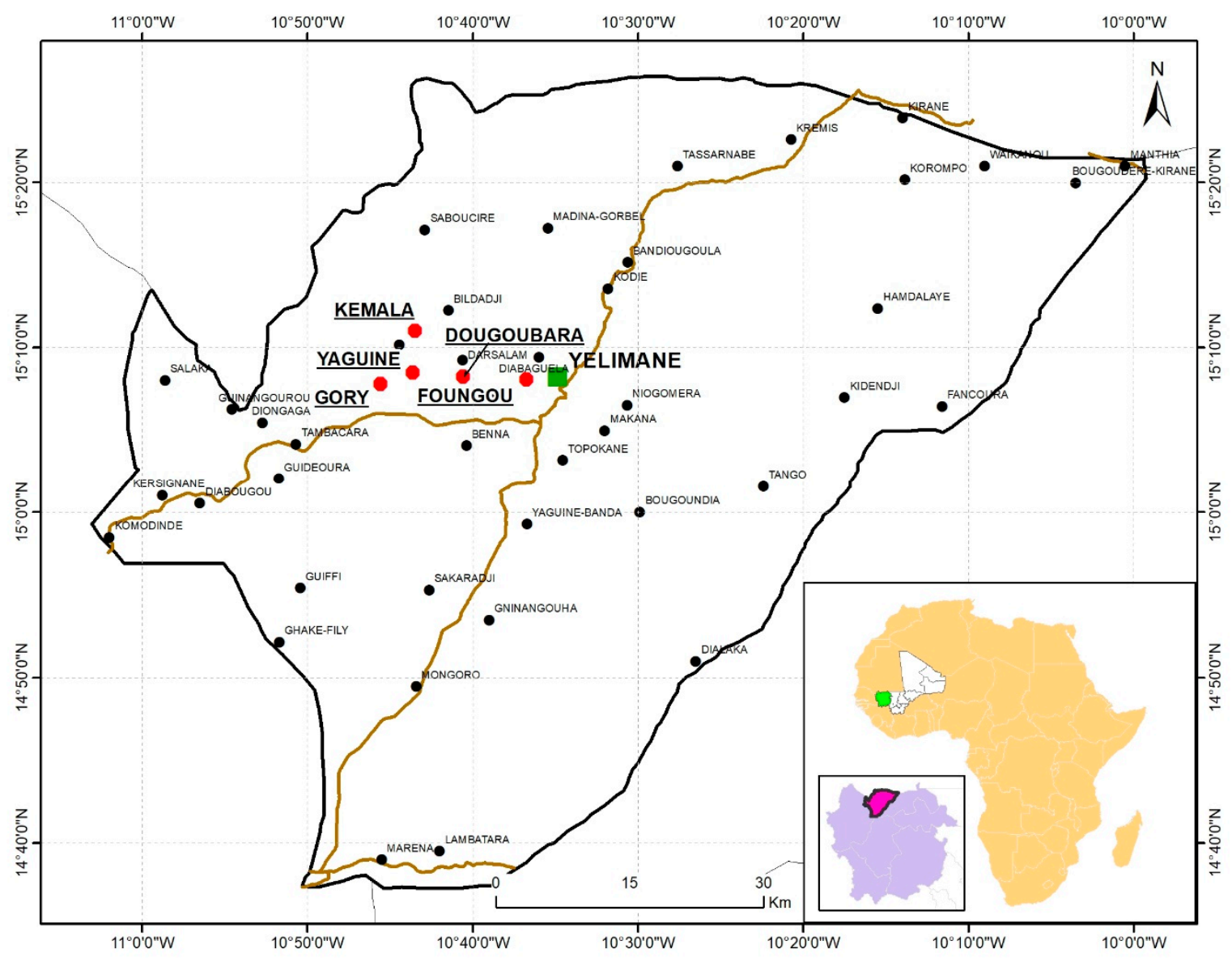

Figure 1. Location of the study area.

The dominant soil types are hydromorphic flood plain with gley and pseudogley hydromorphic soils (PIRT, 1986) and USDA (Aqualfs). Old alluvial plains and terraces were also represented and were characterized as Plinthic haplustalfs. Composite soil samples were collected in six farmers' fields in May at 0-20 cm depths before the establishment of the experiment in each site to determine the main physico-chemical properties.

\subsection{Climatic Condition}

Rainfall data for 2014-2015-2016 of Yélimané are shown in Figure 2. The area received between 500 to $600 \mathrm{~mm}$ of rainfall during the study period. Rainfall is unimodal, with the maximum rainfall events occurring in July and August. Rainfall is highly variable within the year as shown by Figure 2 . The average minimum monthly temperatures during the year ranged from 20.2 to $28.5^{\circ} \mathrm{C}$ while the maximum monthly temperatures ranged from 32.9 to $42.5^{\circ} \mathrm{C}$. The crops in flood recession farming are planted at the end of the rainy season (October/November), when water starts to recede.

\subsection{Field Experiments}

To assess different options for the intensification of sorghum flood recession farming, we conducted five different experiments. These experiments were crop establishment (1), tillage and urea application (2), varieties and crop management (3), fertilization (4), and sorghum varieties (5).

The participatory on-farm experiments were conducted in Yaguine, Gory, Dougoubara, Foungou, and Kémala villages using a randomized block design where a farm represented a replication. The number of replications varied according to the research topics. 
The experimental area of each experimental replication was $39 \mathrm{~m} \times 5 \mathrm{~m}\left(195 \mathrm{~m}^{2}\right)$. The plot size of each treatment was $5 \mathrm{~m} \times 4 \mathrm{~m}\left(20 \mathrm{~m}^{2}\right)$ with two border rows. In all the experiments, the planting density was $1.0 \mathrm{~m} \times 0.5 \mathrm{~m}$ and one seed was placed in each hole corresponding to a density of 40,000 seeds ha ${ }^{-1}$. The experiments were conducted in the 2014/2015 and 2015/2016 cropping seasons. The local variety of sorghum (Sorghum bicolor L. Moench), called magaleme in the Soninke language, was used for the experiments on crop establishment, tillage and urea application, and fertilization. In the variety trials, the local variety Same was used. These two local varieties have a growth cycle of 90 days. Both the Mageleme and Same varieties are considered by the farmer as well adapted to the environment. The plots were weeded once using a hoe.

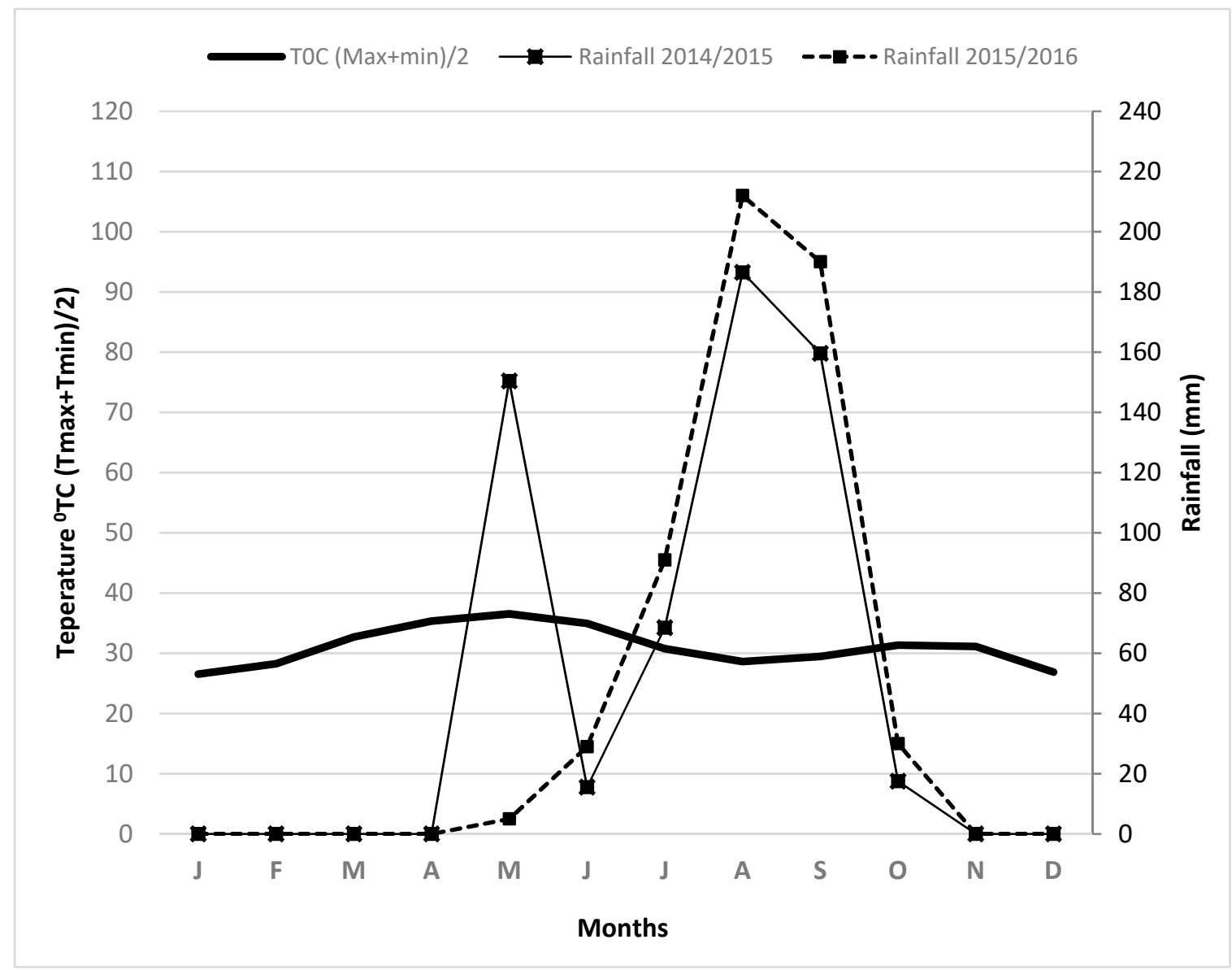

Figure 2. Ombrothermic diagram (Bagnouls and Gaussen) during the 2014/2015 and 2015-2016 cropping season in Yélimané, Mali.

The crop establishment experiment was conducted in the locations Yaguine, Gory, Dougoubara, and Foungou. Each year, there were five replications (farmers) at each location.

The treatments were as follows:

1. Farmers' practices without input.

2. Seed priming + seed treatment with pesticide $+25 \mathrm{~kg}$ urea/ha applied as microdosing. Seed priming consisted of soaking seeds in water for $8 \mathrm{~h}$ followed by drying under shade for one hour. The seeds were thereafter treated with Insector (Imidaclopride $350 \mathrm{~g} / \mathrm{kg}$ + Thirame $100 \mathrm{~g} / \mathrm{kg}$ ).

3. Transplanting of seedlings $+25 \mathrm{~kg}$ urea/ha applied as microdosing. The seedlings were raised from seeds treated with Insector (Imidaclopride $350 \mathrm{~g} / \mathrm{kg}$ + Thirame $100 \mathrm{~g} / \mathrm{kg}$ ). 
The tillage and urea application experiment was a factorial study, with tillage and urea application as the main factors. Each factor had two levels. The experiment was implemented in the locations Yaguine, Gory, Dougoubara, and Foungou. For each location, there were four replications.

The treatments were as follows:

Factor 1. Tillage.

1. Without tillage (farmers' practice).

2. Mounding (soil was heaped to give roots a greater volume of soil and to close cracks in the soil).

Factor 2. Fertilization.

1. Without urea.

2. $25 \mathrm{~kg}$ urea ha ${ }^{-1}$.

The varieties and crop management experiment was implemented in the sites Yaguine, Gory, Dougoubara, and Foungou in the 2014/2015 and in the sites Yaguine, Gory, Dougoubara, Fanga, Tabaka, Dialaka, Diakone, Tambacara, and Dogofry in the year 2015/2016 season. This was a factorial experiment with 2 factors each having 2 treatments (levels). In 2014/2015, there were 16 replications (farmers) for each location whereas in 2015/2016 there were 9 replications (farmers) for each location. The treatments were as follows:

Factor 1 Varieties:

1. Magaleme.

2. Seguifa.

Factor 2 Crop management:

1. 400,000 plant/ha.

2. 660,000 plants ha $+25 \mathrm{~kg}$ urea ha $^{-1}+500 \mathrm{~kg}$ manure ha $^{-1}$ applied as microdosing.

Both the Magaleme and Seguifa varieties have a growth cycle of 90 days.

The fertilization experiment was conducted at the sites Gory, Yaguiné Tringa, Fanga, Marekafo, Diafounou-Gory, Soumpou, and Dougoubara in the 2014/2015 season and at the sites Yaguine, Gory, Dougoubara, Fanga, Tabaka, Dialaka, Diakone, Tambacara, and Dogofry in the 2015/2016 cropping season. In the 2014/2015 season, there were 9 replications (farmers) at each location while in the 2015/2016 season, there were 10 replications.

The treatments were as follows:

1. No fertilizer application.

2. $18 \mathrm{~kg}$ NPK (15-15-15) ha ${ }^{-1}$ applied as microdosing $+500 \mathrm{~kg}$ farmyard manure ha ${ }^{-1}$ applied as microdosing.

The sorghum variety experiment was implemented in the sites Tambacara, Fanga, Dougoubara, Foungou, Yaguine, and Niogomera in 2014/2015 and in the Tambacara, Fanga, Dougoubara, Foungou, Yaguine, Lambatra, and Niogomera locations in the 2015/2016 cropping seasons. In 2014/2015 and 2015/2016, there were 6 and 7 replications for each location, respectively.

The varieties tested were as follows:

1. Same (local variety).

2. Yelimane 1.

3. Yelimane 2.

4. Yelimane 3. 
The improved varieties were developed strictly for the flood recession agriculture in the period from 2011 to 2014 by IER breeders. The varieties tested were early maturing varieties with a growth cycle of 85 to 90 days. All the varieties received $50 \mathrm{~kg} \mathrm{NPK} \mathrm{ha}^{-1}+1$ ton farmyard manure ha ${ }^{-1}+50 \mathrm{~kg}$ urea ha ${ }^{-1}$ (topdressing). The farmyard manure contained $1.73 \%$ nitrogen and had a $\mathrm{C} / \mathrm{N}$ ratio of 20 . The $\mathrm{pH}$ was 6.5. The farmyard manure was placed next to the seeds. Urea was applied 19 days after sowing. Data were collected on grain and stover yield (sun dried) and 1000 grains weight were measured.

\subsection{Soil and Sediment Sampling}

The soil sample taken from each site consisted of seven subsamples. The soil sediments were collected by placing four iron-sheets each measuring $1 \mathrm{~m} \times 1 \mathrm{~m}$ prior to flooding. The sediments were collected and weighed after the withdrawal of water from the land. Particle size analysis was done by the hydrometer method [13], $\mathrm{pH}$ was determined by the electrometric method in a soil solution with a soil/water ratio of 1/2.5 [14], soil organic $C$ was determined using modified Walkley-Black wet oxidation method [15], and the total nitrogen was determined by the Kjeldahl digestion method [16]. The bases, cation exchange capacity (CEC), and available P were determined as described in [17].

\subsection{Socioeconomic Issues}

Individual interviews were conducted in the five villages (Foungou, Dougoubara, Kemala, Yaguine, and Gory). In total, $30 \%$ of the targeted population corresponding to 364 heads of households were randomly selected from these villages. The survey questionnaire focused on structural data of the household, their equipment, livestock, the use of organic and mineral fertilizer, land ownership, cropping systems, and field size in the flood recession plains.

\subsection{Statistical Analysis}

The statistical analysis was undertaken using MINITAB statistical software (Release 14 for Windows) models. The effects of treatments were considered significant at the probability threshold of $p<0.05$. The Newman-Keuls test was used for separating the treatments.

\section{Results}

The result chapter describes the socioeconomic and agronomic characteristics of the flood recession farming system followed by a description of the qualities of the soil and the sediments deposited in the flood recession farming system. Furthermore, we present the results from the field experiments that were installed to explore different ways to improve the productivity of the system.

\subsection{Description of Flood Recession Farming in Yelimane}

Farmers practicing flood recession farming in the Yelimane area only used traditional technologies. There are on average 22 people per household, and of these, there are 11 active workers per household (Table 1). In addition, three persons are working abroad per household. In general, land inheritance is the most common land acquisition method in the flood recession system. Each farm has on average 1.97 ha (range 1.44 to $2.92 \mathrm{ha}$ ) under flood recession farming.

Planting/sowing follows the withdrawal of water and is carried out from the end of September to the first week of November. Crops grown under flood recession farming in the Yelimane areas do not receive any rainfall. Mounding and weeding take place in November according to $62 \%$ of the producers. Harvests and threshing are in the most cases carried out in February to March. The average yield was $750 \mathrm{~kg} \mathrm{ha}^{-1}$ for sorghum and $800 \mathrm{~kg} \mathrm{ha}^{-1}$ for maize.

Farmers do not till the soil prior to sowing. Sorghum/cowpea intercropping with traditional varieties is the dominant cropping system and farmers do not use inputs like mineral fertilizer and pesticides. Only $1 \%$ of the farmers used mineral fertilizer and $4 \%$ of the farmers used herbicides, 
fungicides, or insecticides. Organic fertilizer is, on the other hand, used by $98 \%$ of the farmers, and $70 \%$ of the farmers consider soil fertility to be good. Most of the farmyard manure is applied to rain-fed crops. The amount of seed used per hectare in flood recession agriculture was on average $15.5 \mathrm{~kg} \mathrm{ha}^{-1}$ for sorghum, $12.6 \mathrm{~kg} \mathrm{ha}^{-1}$ for maize, and $3.8 \mathrm{~kg} \mathrm{ha}^{-1}$ for cowpea (generally intercropped with cereals in the same seed hole). Farmers plant sorghum at 1 to $1.5 \mathrm{~m}$ between rows and 0.70 to $0.8 \mathrm{~m}$ between plants in the row, giving a plant density of 12,500 to 20,000 plants ha ${ }^{-1}$. Sowing requires three to four people. The first person uses a hoe to make a planting basin at a depth of $20 \mathrm{~cm}$. This ensures optimal humidity for plant establishment. The second person pierces a hole using a dipple stick called Dopadé and Lougal in the Soninké and Fulani languages, respectively. The third person places the seeds in the hole. Sometimes, a fourth person covers the seed with a handful of sand on heavy clay soils. According to Traore (2017), sowing is undertaken following water withdrawal.

Table 1. Characterization of the households and cropping systems in flood recession farming systems in the district of Yelimane (Kayes region).

\begin{tabular}{|c|c|}
\hline Farm Characteristics & $\%$ of Respondent Households \\
\hline Sorghum/cowpea cropping system & 97 \\
\hline Use of local variety & 87 \\
\hline Good fertility of flood recession plains & 70 \\
\hline Use of organic manure & 98 \\
\hline Use of mineral fertilizer & 1 \\
\hline Use of pesticides, herbicides, fungicides & 4 \\
\hline $\begin{array}{c}\text { Planting density ( } 1-1.5 \mathrm{~m} \text { between and } 0.7-0.8 \mathrm{~m} \\
\text { within rows) }\end{array}$ & 78 \\
\hline Men land ownership & 99 \\
\hline Women land ownership & 1 \\
\hline Men household head & 99 \\
\hline Farm management & Quantity per household \\
\hline Organic manure tons $\mathrm{ha}^{-1}$ & 3.3 \\
\hline $\begin{array}{l}\text { Hectares under flood recession farming per } \\
\text { household }\end{array}$ & 1.7 \\
\hline Number of agricultural workers in the household & 8.2 \\
\hline Livestock & No. per household \\
\hline Cattle & 2.7 \\
\hline Sheep & 6.2 \\
\hline Goat & 3.3 \\
\hline Donkey & 1.5 \\
\hline Horse & 0.14 \\
\hline Dromedary & 0 \\
\hline Poultry & 3.5 \\
\hline Farm equipment & No. per household \\
\hline Tractor & 0 \\
\hline Plough & 1.2 \\
\hline Cart & 1.1 \\
\hline Wheelbarrow & 0.3 \\
\hline Hoe & 6.4 \\
\hline IER Seeder ("dopade") & 1.2 \\
\hline
\end{tabular}

\subsection{Properties of Soils and Sediments}

Analysis of the soil texture showed that all the soils used in soil recession farming contained less than $10 \%$ sand. The soils fell into the categories of clay or silty clay loam.

The $\mathrm{pH}$ of the soil ranged from 6.23 to 7.33 (Table 2). The soil of Dougoubara had a higher $\mathrm{pH}$ and higher available $\mathrm{P}$ than the soils at the two other sites but a lower exchangeable $\mathrm{K}$ than the other 
sites (Table 2). There was no variation between the sites with regard to the total nitrogen and cation exchange capacity. The average soil organic and nitrogen content of the soils were $0.48 \%$ and $0.05 \%$, respectively, while the average $\mathrm{P}$ level was $16.3 \mathrm{ppm}$. The average content of exchangeable $\mathrm{Ca}, \mathrm{Mg}, \mathrm{K}$, and $\mathrm{Na}$ was $6.70,3.29,0.52$, and 0.16 (meq/100 g), respectively. The cation exchange capacity was 11.6 $\mathrm{meq} / 100 \mathrm{~g}$. Soil acidity does not appear to be a limiting factor in these soils. The $\mathrm{Ca} / \mathrm{Mg}$ ratio and $\mathrm{K} / \mathrm{mg}$ were 2.03 and 5.9. The $\mathrm{Ca} / \mathrm{Mg}$ ratio was 2.03 while the $\mathrm{Mg} / \mathrm{K}$ ratio was 5.9.

Table 2. Chemical properties of soils from the sites of Gory, Dougoubara, and Yaguiné in the district of Yelimane (Kayes).

\begin{tabular}{cccc}
\hline & Gory & Dougoubara & Yaguine \\
\hline pH $\mathrm{H}_{2} \mathrm{O}$ & 6.75 & 7.33 & 6.23 \\
Organic Matter $(\% \mathrm{C})$ & 0.42 & 0.41 & 0.62 \\
Total N (\%) & 0.05 & 0.05 & 0.06 \\
Available P (ppm) & 10.43 & 27.53 & 11.08 \\
Exchangeable $\mathrm{Ca}(\mathrm{meq} / 100 \mathrm{~g})$ & 7.09 & 5.49 & 7.54 \\
Exchangeable $\mathrm{Mg}(\mathrm{meq} / 100 \mathrm{~g})$ & 3.51 & 2.71 & 3.67 \\
Exchangeable $\mathrm{K}(\mathrm{meq} / 100 \mathrm{~g})$ & 0.62 & 0.33 & 0.62 \\
Exchangeable $\mathrm{Na}\left(\mathrm{meq}^{\prime} 100 \mathrm{~g}\right)$ & 0.13 & 0.25 & 0.12 \\
CEC $\left(\mathrm{cmol} \mathrm{kg}^{-1}\right)$ & 11 & 12 & 12 \\
\hline
\end{tabular}

It appeared that the sediments were not richer than the soil on which the sediments were deposited (Table 3). Soil pH (water) in the deposited sediments were slightly more acidic than the soil on which they were deposited. The average carbon and nitrogen content were $0.50 \%$ and $0.026 \%$, respectively. The phosphorous levels in the sediments were also at the same level as the phosphorous levels in the soil. The average content of exchangeable $\mathrm{Ca}, \mathrm{Mg}, \mathrm{K}$, and $\mathrm{Na}$ in the soil was $14.31,4.7,0.52$, and 0.12 (meq/100 g), respectively. The sediments were slightly richer than the soil with regard to Ca but were at the same level for $\mathrm{Mg}$ and $\mathrm{K}$.

Table 3. Chemical analysis of soils from deposit sediments in flood recession farming.

\begin{tabular}{cccc}
\hline Sites & Gory & Dougoubara & Yaguine \\
\hline pH H $\mathrm{H}_{2} \mathrm{O}$ & 6.27 & 6.28 & 6.51 \\
Organic Matter (\% C) & 0.37 & 0.59 & 0.55 \\
Total N (\%) & 0.03 & 0.03 & 0.02 \\
Available P (ppm) & 21.34 & 9.63 & 10.32 \\
Exchangeable Ca (meq/100 g) & 13.00 & 15.80 & 14.15 \\
Exchangeable Mg meq/100 g) & 6.49 & 6.75 & 7.06 \\
Exchangeable K (meq/100 g) & 0.64 & 0.75 & 0.62 \\
Exchangeable Na (meq/100 g) & 0.17 & 0.12 & 0.09 \\
CEC (meq/100 g) & 20.07 & 27.13 & 22.07 \\
\hline
\end{tabular}

\subsection{Field Experiments}

The field experiments included studies of on crop estblishment (1), tillage and urea application (2), varieties and crop management (3), fertilizer application (4), and sorghum varieties (5). These experiments explored different options for increasing the productivity of sorghum under flood recession conditions.

The experiment on crop establishment showed that there were significant differences between the methods (Table 4). Seed priming combined with seed treatment with a pesticide and urea application increased the grain yield compared to the control by $77.1 \%$, while seedling transplantation combined with pesticide application and urea increased the yield by $61.3 \%$. The treatment including seed priming increased the stover yield compared to the control by $35.3 \%$, while the treatment including seedling transplantation increased the stover yield by $15.1 \%$. There was no interaction between years and 
treatments. The seed priming treatment and the seedling transplantation treatment increased the TGW compared to the control by 20.1 and $10.9 \%$, respectively.

Table 4. Effects of the planting technique on the sorghum grain and straw yield $\left(\mathrm{kg} \mathrm{ha}^{-1}\right)$ and thousand grain weight (TGW). Average for the 2014/2015-2015/2016 cropping seasons.

\begin{tabular}{cccc}
\hline & Grain $\mathbf{~ k ~ h a ~}^{\mathbf{- 1}}$ & Straw kg ha & TKW $(\mathbf{g})$ \\
\hline Method & & & \\
Farmer's practice & $994 \mathrm{~b}$ & $3445 \mathrm{c}$ & $23.8 \mathrm{c}$ \\
Transplanting & $1604 \mathrm{a}$ & $3964 \mathrm{~b}$ & $26.4 \mathrm{~b}$ \\
Seed priming & $1761 \mathrm{a}$ & $4633 \mathrm{a}$ & $28.6 \mathrm{a}$ \\
\hline Probability & 0.0001 & $<0.0001$ & $<0.0001$ \\
\hline Interactions & & Probability & \\
Technique $\times$ Year & 0.4070 & $<0.0001$ & 0.0189 \\
Mean & 1453 & 4014 & 26.27 \\
SE & 110 & 136 & 0.250 \\
CV\% & 41.4 & 18.5 & 5.2 \\
\hline
\end{tabular}

$\mathrm{a}, \mathrm{b}$ : values in the same column with different letters are significantly different at $p=0.05$. SE: standard error, CV: coefficient of variation.

The tillage and urea application experiment showed that the sorghum grain productivity under mounding was $34 \%$ greater than the non-mounding treatment (farmers' practice) (Table 5). Urea application increased the grain yield from $1248 \mathrm{~kg} \mathrm{ha}^{-1}$ in the control kg to $1559 \mathrm{~kg} \mathrm{ha}^{-1}$ when 25 urea $\mathrm{ha}^{-1}$ was applied. Both the mounding and urea application increased the stover yield, but this effect was not significant.

Table 5. Effects of mounding on the sorghum grain and straw yield $\left(\mathrm{kg} \mathrm{ha}^{-1}\right)$ and thousand grain weight (TGW). Average for the 2014/2015-2015/2016 cropping seasons.

\begin{tabular}{|c|c|c|c|}
\hline & Grain kg ha ${ }^{-1}$ & Straw kg ha ${ }^{-1}$ & TGW (g) \\
\hline \multicolumn{4}{|l|}{ Tillage } \\
\hline No Mounding & $1199 b$ & 4301 & 26.91 \\
\hline Mounding & $1608 \mathrm{a}$ & 4519 & 27.28 \\
\hline Probability & 0.0011 & 0.2456 & 0.5322 \\
\hline \multicolumn{4}{|l|}{ Fertilization } \\
\hline No Fertilization & $1248 b$ & 4359 & $26.28 b$ \\
\hline Urea $\left(25 \mathrm{~kg} \mathrm{ha}^{-1}\right)$ & $1559 a$ & 4461 & $28.02 a$ \\
\hline Probability & 0.0096 & 0.5820 & 0.0098 \\
\hline Interactions & & Probability & \\
\hline Fertilization $\times$ Tillage & 0.666 & 0.9811 & 0.0786 \\
\hline Fertilization $\times$ Year & 0.382 & $<0.001$ & 0.0610 \\
\hline Tillage $\times$ Year & 0.021 & 0.7557 & 0.2705 \\
\hline $\begin{array}{c}\text { Fertilization } \times \text { Tillage } \\
\times \text { Year }\end{array}$ & 0.587 & 0.4066 & 0.8566 \\
\hline Mean & 1404 & 4410 & 27.09 \\
\hline SE & 78 & 129 & 0.411 \\
\hline $\mathrm{CV} \%$ & 30.7 & 16.5 & 8.5 \\
\hline
\end{tabular}

$\mathrm{a}, \mathrm{b}$ : values in the same column with different letters are significantly different at $p=0.05$. SE: standard error, TGW: thousand grain weight, CV: coefficient of variation.

Mounding had no significant effect on TGW while urea application increased TGW by $6.6 \%$ compared to the control. No interaction was found between tillage and fertilizer application on any of the studied parameters. 
The varieties and crop management experiment showed that the grain yield of the improved sorghum variety Seguifa was 20\% higher compared to the local variety Magaleme $(p<0.0001)$ (Table 6). A highly significant difference $(p<0.0001)$ was observed between the varieties with regard to TGW. The TGW of Seguifa was $18 \%$ higher than that of the local variety Magaleme (Table 6).

Table 6. Effects of varieties and crop management on sorghum grain and straw yield $\left(\mathrm{kg} \mathrm{ha}^{-1}\right)$ and thousand grain weight (TGW). Average for the 2014/2015 and2015/2016 cropping seasons.

\begin{tabular}{|c|c|c|c|}
\hline & Grain kg ha $\mathrm{a}^{-1}$ & Straw kg ha $\mathbf{a}^{-1}$ & TGW (g) \\
\hline \multicolumn{4}{|l|}{ Varieties } \\
\hline Magaleme & $1229 b$ & 3919 & $24.3 b$ \\
\hline Seguifa & $1472 \mathrm{a}$ & 3987 & $28.6 \mathrm{a}$ \\
\hline Probability & $<0.0001$ & 0.6590 & $<0.0001$ \\
\hline \multicolumn{4}{|l|}{ Crop management } \\
\hline 40000 plants ha $^{-1}$ & $1095 b$ & $4168 \mathrm{a}$ & 26.5 \\
\hline $\begin{array}{c}66,000 \text { plants ha }{ }^{-1}+25 \mathrm{~kg} \text { urea } / \mathrm{ha}+500 \mathrm{~kg} \\
\text { farm yard manure ha }{ }^{-1}\end{array}$ & $1606 a$ & $3738 b$ & 26.3 \\
\hline Probability & $<0.0001$ & 0.006 & 0.5274 \\
\hline Interactions & & Probability & \\
\hline Varieties $\times$ Crop management & 0.34 & 0.0933 & 0.8386 \\
\hline Mean & 1351 & 3953 & 26.4 \\
\hline SE & 43.41 & 108 & 0.201 \\
\hline $\mathrm{CV} \%$ & 28.7 & 24.9 & 6.8 \\
\hline
\end{tabular}

$\mathrm{a}, \mathrm{b}$ : values in the same column with different letters are significantly different at $p=0.05$. SE: standard error, CV: coefficient of variation.

An increasing planting density from 40,000 to 66,000 plants ha ${ }^{-1}$ combined with $25 \mathrm{~kg}_{\mathrm{urea}} \mathrm{ha}^{-1}+$ $500 \mathrm{~kg}$ manure ha ${ }^{-1}$ applied as microdosing increased the grain yield by $46.9 \%$, while the stover yield decreased by $11 \%$ ha as a result of an increased population density and fertilization. There was no effect of planting density on TWG.

Application of $18 \mathrm{NPK} \mathrm{ha}^{-1}$ and $500 \mathrm{~kg}_{\text {farmyard manure ha }}{ }^{-1}$ (both applied as microdosing) in the fertilizer experiment increased the grain yields by $74 \%$ and the stover yield by $22.3 \%$ (Table 7 ). The TGW increased by $31 \%$ as a result of fertilization compared to the farmer's practice.

Table 7. Effects of fertilization on the sorghum grain and straw yield $\left(\mathrm{kg} \mathrm{ha}^{-1}\right)$ and thousand grain weight (TGW). Average for the 2014/2015 and2015/2016 cropping seasons.

\begin{tabular}{|c|c|c|c|}
\hline & Grain kg ha-1 & Straw $\mathrm{kg} \mathrm{ha}^{-1}$ & TGW (g) \\
\hline \multicolumn{4}{|l|}{ Fertilization } \\
\hline No Fertilization & $955 b$ & $3291 b$ & $23.93 b$ \\
\hline $\mathrm{NPK}+\mathrm{OM}$ & $1658 \mathrm{a}$ & $4025 a$ & $28.88 \mathrm{a}$ \\
\hline Probability & $<0.0001$ & 0.0198 & $<0.0001$ \\
\hline Fertilization $\times$ Year & $<0.001$ & 0.4662 & 0.2222 \\
\hline Mean & 1307 & 3658 & 26.40 \\
\hline SE & 67.9 & 212 & 0.221 \\
\hline $\mathrm{CV} \%$ & 32 & 35 & 5.1 \\
\hline
\end{tabular}

$\mathrm{a}, \mathrm{b}$ : values in the same column with different letters are significantly different at $p=0.05$. SE: standard error, CV: coefficient of variation.

The sorghum varieties experiment showed that the varieties Yelimane 1, Yelimane 2, and Yelimane 3 produced a 56.9\%,61.5\%, and 36.6\% higher yield than the local variety Same (Table 8). The corresponding increase in the stover yield for the three improved varieties compared to the local 
variety were $57.0 \%, 77.4 \%$, and $37.5 \%$. The TGW values of the improved varieties were in the order of $12.9 \%$ to $14.9 \%$ higher for the improved varieties. There was no interaction between the variety and year.

Table 8. Grain yield, straw yield $\left(\mathrm{kg} \mathrm{ha}^{-1}\right)$, and thousand grain weight (TGW) of three new varieties and one local variety. Average for the 2014/2015-2015/2016 cropping seasons.

\begin{tabular}{|c|c|c|c|}
\hline & Grain kg ha-1 & Straw kg ha ${ }^{-1}$ & TGW (g) \\
\hline \multicolumn{4}{|l|}{ Varieties } \\
\hline Same & $1021 c$ & $3142 d$ & $24.8 \mathrm{~b}$ \\
\hline Yelimane1 & $1602 a$ & $4933 b$ & $28.3 a$ \\
\hline Yelimane2 & $1649 a$ & $5577 a$ & $28.0 \mathrm{a}$ \\
\hline Yelimane3 & $1405 b$ & $4321 c$ & $28.5 a$ \\
\hline Probability & $<0.0001$ & $<0.0001$ & $<0.0001$ \\
\hline Interactions & Probability & & \\
\hline Varieties $\times$ Year & 0.3053 & 0.6278 & 0.0628 \\
\hline Mean & 1419 & 4493 & 27.40 \\
\hline SE & 47.38 & 171 & 0.176 \\
\hline CV\% & 24.9 & 28.5 & 4.8 \\
\hline
\end{tabular}

$\mathrm{a}, \mathrm{b}, \mathrm{c}, \mathrm{d}$ : values in the same column with different letters are significantly different at $p=0.05$. SE: standard error, $\mathrm{CV}$ : coefficient of variation.

\section{Discussion}

\subsection{Characteristics of the Flood Recession Farming Environment}

Flood recession farming is a supplement to rainfed agriculture in the Yelimane area as the system gives a yield five to six months after the harvest of the rainfed crops. The survey showed that farmers hardly used any input. This low use of input is probably a result of distance to the input market, low purchasing power of the farmers, and limited access to agricultural extension on flood recession farming. Farmers also considered the soils in flood recession farmers to be of good soil fertility, and this may also explain why the use of mineral fertilizer is minimal. Other studies $[18,19]$ have also confirmed that farmers think that soils have good fertility.

\subsection{Soil Characteristics}

The soil analysis showed that the soil in these flood recession farming systems is low in soil organic carbon and nitrogen. The average soil organic carbon content was $0.5 \%$ while the average N\% content was $0.053 \%$. A typical sahelian soil with $90 \%$ sand will be exposed to physical degradation if the soil contains less than $0.6 \%$ soil organic carbon [20]. The average soil organic nitrogen content was $0.053 \%$, which is considered a very low level [21]. The average phosphorous content of the soil was $8 \mathrm{mg} \mathrm{kg}^{-1}$. For tropical soils, a critical level of $8 \mathrm{mg} \mathrm{kg}^{-1}$ has been found [22]. For Malian soils, it was reported that the critical level is $7 \mathrm{mg} \mathrm{kg}^{-1}$ [23]. Phosphorous therefore does not seem to be a limiting factor for soils under flood recession farming in the Yelimane area. The average content of exchangeable $\mathrm{Ca}, \mathrm{Mg}$, $\mathrm{K}$, and $\mathrm{Na}$ indicate that these nutrients are not limiting for plant growth [21]. $\mathrm{The} \mathrm{Ca} / \mathrm{Mg}$ and $\mathrm{Mg}$ in the soil were 2.03 and 5.9, respectively. The optimum range for the $\mathrm{Ca} / \mathrm{Mg}$ ration is from 1.5 to 5 and for $\mathrm{Mg} / \mathrm{K}$ from 2 to 5 [24]. The cation exchange capacity was $11.6 \mathrm{meq} / 100 \mathrm{~g}$, which is considered a low value [21]. This low CEC is probably a reflection of the low soil organic carbon level [25].

It appeared that the sediments cannot contribute to improving the soil chemical properties of the soil in the Yelimane as the deposited sediments were not richer than the soil on which the sediments were deposited. However, the yearly supply of sediments will contribute to maintaining the properties of the soils. The available phosphorous in the sediments was also at the same level as in the soils. The sediments contained almost twice as much exchangeable $\mathrm{Ca}$ and $\mathrm{Mg}$ as in the soil while the 
exchangeable potassium level was at the same level in soils and in the sediments. Studies from Mauritania have also shown that the soils used for flood recession farming are low in soil organic matter and nitrogen [26].

Based on the chemical analysis of the soil and the sediments, it appears that there is a particular need to use fertilizers that are rich in nitrogen as the nitrogen content of the soil and the sediments are very low. The phosphorous levels in the soil were slightly above the critical levels, but since the sediments do not contribute much to improving the phosphorous levels in the soil, there might be a need for a small annual application to compensate for the loss of phosphorous with the harvest. There appears to be no particular need for the application of calcium, magnesium, and potassium as these levels were above the critical levels in the soils and in the sediments. The application of organic fertilizer has been suggested to be particularly important in flood recession farming [26]. The survey also showed that farmers in the area do use organic fertilizer to maintain soil fertility.

\subsection{Field Experiemts}

This study showed that the sorghum yield in flood recession farming in the Yelimane district can be significantly increased by introducing simple and low-cost technologies. The grain yield varied from 950 to $1200 \mathrm{~kg} \mathrm{ha}^{-1}$ under traditional management whereas the grain yield was up to $1750 \mathrm{~kg} \mathrm{ha}^{-1}$ under improved management. There was in addition a significant increase in the stover yield under the improved management. These yield levels are above what is experienced in rainfed conditions in Mali under a similar rainfall regime [11]. The yield in flood recession farming will in addition be more stable, as the water supply in the flooded areas will not be so dependent on rainfall variability within the rainy season. Flood recession farming also spreads the labor over the year and allows farmers to have a harvest at the beginning of the hot and dry season when food is often in short supply. The straw produced at this time will in addition be a very important source of fodder for securing the survival of livestock during this harsh period of the year.

The survey showed that farmers use traditional farming methods without any use of input. Several methods were identified that can increase the yield in flood recession farming in Yelimane. Crop establishment methods, tillage, fertilization, and improved varieties gave a higher yield than the traditional farming methods. Farmers may not be able to use all these methods, but their choice will depend on the availability of and access to inputs (seeds and fertilizer), the price of the inputs, and the labor demand of the technologies.

Seed priming in combination with fertilizer appears to be an appealing approach for the farmers as this treatment increased the grain yield by $77.1 \%$ while the additional labor demand is low. It has previously been shown that seed priming or transplanting in combination with $1 \mathrm{~g}$ urea per planting hill increased the yield by $104 \%$ and $97 \%$, respectively, in flood recession farming in Yelimane [2]. The yield benefit of seed priming and fertilizer in these experiments is higher than the results obtained when these methods were tested under rainfed conditions [27]. Seed priming in the tropics has been found to improve crop growth and plant vigor [28]. The use of seedling transplantation also increased the yield, but the high labor demand associated with the method makes this approach less attractive. It may also be a problem for the farmers to have access to seedlings at the optimal development stage when water starts to recede. Sorghum plots established by transplanting reached the $50 \%$ flowering stage 15-20 days earlier than those resulting from direct seedlings. This corroborates the work from Ethiopia that showed a difference of 10-14 days between the flowering dates of transplanted and direct seeding plants in Ethiopia [29]. The benefit from seed priming and transplanting may be a result of less end-of-season drought and reduced attack of birds and pests like grasshoppers [29]. The higher TGW in plots established using transplanting and priming may also be an effect of better water conditions in the soil at the later stages in the development cycle of the crop.

The use of NPK and urea also appeared to be attractive options for increasing the yield. Access to mineral fertilizer in the district may be an issue as the survey showed there is no tradition for using mineral fertilizer in this area. An increase of $319 \mathrm{~kg} \mathrm{ha}^{-1}$ was recorded using microdosing of urea 
compared to the control. One reason why the yield increased as a result of urea application was better grain filling. A response to nitrogen fertilizer can be expected in the area because the soil analysis showed a very low nitrogen content $(0.05 \%)$.

The combination of microdosing of NPK fertilizer and farmyard manure resulted in increased grain by $74 \%$. This shows that contrary to most farmers' views, fertilization is needed in order to achieve a good yield under flood recession farming [2]. The annual application of nutrients and particularly nitrogen is needed in flood recession farming as nutrients are removed by the harvest, leaching, and soil erosion. In the Gourma region of Mali, it has previously been shown that phosphorous can be deficient in flood recession [30]. The availability of manure is a constraint in the area as the survey showed that livestock numbers were low. For this reason, it makes sense to supplement the organic fertilizer with some mineral fertilizer. The use of grain legumes like cowpea should also be promoted in crop rotation as they supply nitrogen to the succeeding crop.

Mounding increased the yield by $409 \mathrm{~kg} / \mathrm{ha}$ compared to the control without tillage, which is comparable to what is found under flood recession farming in Chad [6]. Cracks are formed when clay soils swell and dry, and filling these cracks by mounding eliminates the exposure of the roots to sunlight and reduces evaporation losses from the soil. This operation also reduces attacks from rodents and other pests.

Improved varieties can also be an attractive option for increasing yields as there is no additional labor associated with the use of improved varieties. Introducing new varieties may increase the seed costs, but in most cases, the additional costs are moderate. The sorghum variety experiment showed that the improved varieties increased yields by $36.6 \%$ to $61.5 \%$ compared to the local variety. These improved varieties are particularly selected because of their ability to perform under flood recession farming in the Yelimane area. In the other experiment, it was shown that the grain yield and TGW of the improved Seguifa variety was higher than the traditional variety (Same). Seguifa is an improved variety developed by IER in Mali that can produce a yield of up $3 \mathrm{tha}^{-1}$ under favorable conditions [3].

An increasing plant density in combination with fertilizer application also increased yield by $46.6 \%$ but produced a lesser straw yield than the treatment with a lower plant density. Increasing the planting density therefore seems to improve the development of the reproductive part of the plant at the expense of its vegetative one. Our results corroborate with studies on vertisol in Nigeria that showed that the total dry matter and grain yield of two varieties of sorghum increased as the plant density increased from $20,000^{1}$ to 125,000 plants ha $^{-1}$ [31].

This study assessed farmers' practices in flood recession agriculture and screened different options for enhancing productivity. Low-cost methods for the intensification of flood recession agriculture were identified, but farmers will choose methods based on their resources and the availability of inputs. These options are not yet well known in all the flood recession areas in Mali and there is therefore a need to strengthen the extension service related to flood recession agriculture.

\section{Conclusions}

The agro-ecological conditions are not favorable for rainfed agriculture in the drought-prone Yelimane district in Mali. Flood recession farming represents an alternative production system, which can supplement rainfed production. Flood recession agriculture in the area is practiced using traditional methods, and inputs like improved seeds, mineral fertilizer, and fungicides/insecticides are used to a very limited degree. Farmers are poor, and under such conditions, it makes sense to look for low-cost options for increasing yield. The analysis of soils and sediments showed that the soils are particularly low in nitrogen and this explains the good response to nitrogen fertilizer in the field experiment. Other low-cost methods for increasing yields were seed priming, mounding, increasing plant density, and improved varieties. These technologies increased the yield from $25 \%$ to $77 \%$. Fertilizer application and seed priming also reduced the time to flowering for sorghum. To our knowledge, this is the first study to systematically assess different options for increasing productivity under flood recession farming in West Africa. 
Author Contributions: Conceptualization, K.T., B.T., G.S. and J.B.A.; methodology, K.T. and J.B.A.; software, K.T. and B.T.; validation, K.T., B.T. and J.B.A.; formal analysis, K.T. and B.T.; investigation, K.T. and B.T.; writing—original draft preparation, K.T.; writing—review and editing, B.T., G.S. and J.B.A.; supervision, G.S. and J.B.A.; project administration, K.T.; funding acquisition, G.S. and J.B.A. All authors have read and agreed to the published version of the manuscript.

Funding: This research was funded by The Norwegian Ministry of Foreign Affairs.

Acknowledgments: We would like to thank the involved farmers in Yelimane district for their participation. We would also like to thank the Norwegian Ministry of Foreign Affairs for financing through the project "Adapting crop and livestock systems in Mali to climate change".

Conflicts of Interest: The authors declare no conflict of interest.

\section{References}

1. Allen, R.C. Agriculture and the origins of the state in ancient Egypt. Explor. Econ. Hist. 1997, 34, 135-154. [CrossRef]

2. Traore, B. Amélioration des Techniques de Production du Sorgho de décrue dans le Cercle de Yélimané. Diplôme de Doctorat en Gestion durable des Ressources Naturelles; Institut Supérieur de Formation et de Recherche Appliquée (ISFRA): Bamako, Mali, 2017; 187p.

3. Sidibé, A.; vom Brocke, K.; Coulibaly, H.; Evrard, J.C. Production de Semences de Sorgho en Milieu Paysan au Mali. IER/ICRISAT/CIRAD. 2008. Available online: https://www.cirad.fr/actualites/toutes-les-actualites/ articles/2011/ca-vient-de-sortir/production-de-semences-de-sorgho-en-milieu-paysan-au-mali (accessed on 16 May 2020).

4. Harlan, J.R.; Pasquereau, J.J. Décrue agriculture in Mali. Econ. Bot. 1969, 23, 70-74. [CrossRef]

5. Traore, K.; Aune, J.B.; Traore, B. Effect of Organic Manure to Improve Sorghum Productivity in Flood Recession Farming in Yelimane, Western Mali. Am. Sci. Res. J. Eng. 2016, 23, 232-251.

6. Chantereau, J. Connaissance et utilisation de la diversité des sorghos de décrue en Afrique de l'ouest et du centre au CIRAD. In La culture du sorgho de décrue en Afrique de l'ouest et du centre; Comas, J., MacPherson, H.G., Eds.; Agence Espagnole de Coopération International: Madrid, Spain, 2002; pp. 39-49. Available online: https://www.doc-developpement-durable.org/file/Culture-plantes-alimentaires/FICHES_PLANTES/ sorgho/La\%20culture\%20du\%20sorgho\%20de\%20decrue $\% 20$ en $\% 20$ Afrique $\% 20$ de $\% 201-O$ uest $\% 20$ et $\%$ 20du\%20Centre.pdf (accessed on 17 March 2020).

7. Saarnak, N.L. Flood recession agriculture in the Senegal River Valley. Dan. J. Geogr. 2003, 103, 99-113. [CrossRef]

8. Sanogho, N.N. Rapport National Final d'Analyse Diagnostique Environnementale Transfrontalière du Bassin du fleuve Sénégal- Mali; African Water Information System: Dakar, Sénégal, 2018; Available online: http://www.african-wis.org/document/rapport-national-final-danalyse-diagnostiqueenvironnementale-transfrontaliere-bassin (accessed on 16 May 2020).

9. PROMISAM. Projet de Mobilisation des Initiatives en Matière de Sécurité Alimentaire au Mali. 2007-2011. Plan de sécurité Alimentaire Commune Rurale de Guidime 2007-2011, 13pp, 2007-2011 Commissariat à la sécurité Alimentaire, Bamako, Mali 13pp. 2006. Available online: https://reliefweb.int/sites/reliefweb.int/ files/resources/17F17BA9F7615195C125742F002F22FA-Rapport_Complet.pdf (accessed on 16 May 2020).

10. Seror, R. Les Projets Productifs au Mali et le rôle des Associations de Migrants en France; Cellule technique du Codéveloppement Mali: Bamako, Mali; Available online: https://www.codeveloppementmali.org/IMG/pdf/ productifs_codev_mali.pdf (accessed on 16 May 2020).

11. Aune, J.B.; Traore, C.O.; Mamadou, S. Low-cost technologies for improved productivity of dryland farming in Mali. Outlook Agric. 2012, 41, 103-108. [CrossRef]

12. Traore, K.; Sidibe, D.K.; Coulibaly, H.; Bayala, J. Optimizing yield of improved varieties of millet and sorghum under highly variable rainfall conditions using contour ridges in Cinzana, Mali. Agric. Food Secur. 2017, 6, 11. [CrossRef]

13. Anderson, J.M.; Ingram, J.S.I. A handbook of methods. In Tropical Soil Biology and Fertility, 2nd ed.; CAB International: Wallingford, UK, 1993; pp. 93-95.

14. Jackson, M.C. Soil Chemical Analysis; Prentice Hall of India Private Limited: New Delhi, India, 1967; pp. 38-56. 
15. Nelson, D.W.; Sommers, L.E. Total carbon, organic carbon, and organic matter. In Methods of Soil Analysis; Page, A.L., Ed.; Agronomy No. 9, Monograph Series; American Society of Agronomy: Madison, WI, USA, 1982; pp. 539-579.

16. Bremner, J.M.; Mulvaney, C.S.; Total, N. Methods of Soil Analysis Part 2. Chemical and Mineralogical Properties, 2nd ed.; Page, A.L., Ed.; Agron. Monograph.; ASA-SSSA: Madison, WI, USA, 1982; Volume 9, pp. 595-622.

17. Page, A.L.; Miller, R.H.; Keeney, D.R. Ammonium by colorimetric method-Indophenol blue method. In Method of Soil Analysis Part II-Chemical and Microbiological Properties; American Society of Agronomy: Madison, WI, USA, 1982; pp. 672-676.

18. Cissé, A.M. Système Faguibine: L'Espoir Renait en Zone Lacustre. 2009. Available online: http://malijet. com/actualte_dans_les_regions_du_mali/13798-systeme_faguibine_1_espoir_en_zone.html (accessed on 16 May 2020).

19. Couture, L.J. Bilan et Potentialités des améNagements Hydro-Agricoles en région Septentrionale de Kayes (Mali): Quelles leçons pour le développement Rural régional? Centre National d'Enseignement Agricole des regions chaude-Gestion sociale de l'eau (CNEARC/GSE): Montpellier, France, 1996; Available online: http://www. beep.ird.fr/collect/bre/index/assoc/HASHb236.dir/18-152-173.pdf (accessed on 16 March 2020).

20. Pieri, C. Long-term soil management experiments in semiarid francophone Africa. In Soil management. Experimental basis for sustainability and environmental quality; Lal, R., Stewart, B.A., Eds.; CRC Press: Boca Raton, FL, USA, 1995; pp. 225-266.

21. Landon, J.R. Booker Tropical Soil Manual; Booker Agriculture International Limited: London, UK, $1984 ;$ p. 450.

22. Aune, J.B.; Lal, R. Agricultural productivity in the tropics and critical limits of properties of Oxisols, Ultisols, and Alfisols. Trop. Agric. 1997, 74, 96-103.

23. IER (Institut d'Economie Rurale). Rapport Analytique, Campagne 1999-2000; Laboratoire Sol Eau Plante, CRRA de Sotuba: Bamako, Mali, 2000; p. 27.

24. Dabin, B.; Magnien, R. Les principaux sols d'Afrique de l'ouest et leurs potentialités agricole. Cah. ORSTOM 1979, 17, 235-257.

25. Caravaca, F.; Lax, A.; Albaladejo, J. Organic matter, nutrient content and cation exchange capacity in fine fractions from semi-arid calcareous soils. Geoderma 1999, 93, 161-176. [CrossRef]

26. Comas Gómez, J.; MacPherson, H.; Cañameras, N. Considérations générales sur l'agronomie du sorgho de décrue. Disponibilité de l'eau et des éléments nutritifs. In La culture du sorgho de décrue en Afrique de l'Ouest et du Centre; Comas, J., Gómez MacPherson, H., Eds.; Agence Espagnole de Coopération Internationale: Madrid, Spain, 2001; pp. 51-63. Available online: https://www.doc-developpement-durable. org/file/Culture-plantes-alimentaires/FICHES_PLANTES/sorgho/La\%20culture\%20du\%20sorgho\%20de\% 20decrue\%20en\%20Afrique\%20de\%201-Ouest\%20et\%20du\%20Centre.pdf (accessed on 16 May 2020).

27. Coulibaly, A.; Woumou, K.; Aune, J.B. Sustainable intensification of sorghum and pearl millet production by seed priming, seed treatment and fertilizer microdosing under different rainfall regimes in Mali. Agronomy 2019, 9, 664. [CrossRef]

28. Harris, D. Development and testing of "on-farm" seed priming. Adv. Agron. 2006, 90, 128-178.

29. Assefa, D.; Belay, M.; Tsegay, D.; Haile, M. Transplanting Sorghum as a Means of Ensuring Food Security in Low Rainfall Sorghum Growing Areas of Northern Ethiopia. Dryland Coord. Rep. no 48. 2007, pp. 1-49. Available online: https://www.utviklingsfondet.no/dcg/assets/documents/Publications/634-report_48.pdf (accessed on 16 May 2020).

30. Aune, J.B. La culture de décrue au Gourma, Mali. Conditions pedologiques, espèces et variétés. Nor. J. Agric. Sci. 1992, 6, 279-291.

31. Tabo, R.; Olabanji, O.G.; Ajayi, O.; Flower, D.J. Effect of plant population density on the growth and yield of sorghum varieties grown on a vertisol. Afr. Crop Sci. J. 2002, 10, 31-38. [CrossRef]

(C) 2020 by the authors. Licensee MDPI, Basel, Switzerland. This article is an open access article distributed under the terms and conditions of the Creative Commons Attribution (CC BY) license (http://creativecommons.org/licenses/by/4.0/). 